子との電極表面に括ける嶩度比の $\mathrm{pH}$ とよる变化が考光 られないだるらか。ちなみに、于才セミガルバゾン $=\mathrm{N}-\mathrm{NHCSNH}_{2}$ の場合には、アゾメチン基の加水分解以 外に,上述のような原因による波高の变化が認められた 〔朝日：ポーラログラフ討論绘要旨集, p. 1, 1956, 於 東京了.

上原巳芳 本実唤では，ベンザルアニリンの波高は， 第 1 波，第 2 波とも， pH飞よる变化は認められない。 したがってベンザルアニリンの N-プロトン付加体とそ の解離分子との $\mathrm{pH}$ による濃度比の変化は考息られな

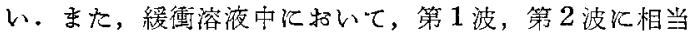
する電位で電解すれば，第 1 波の電位ではジニリノシ
ベンジルが，第 2 波の電位ではベンジルアニリンが得ら れた。るし，2段波が解離分子—非解離分子の平衡に上 るものとすれば，第 1 波，第 2 波のいずれの電位でもべ ンジルアニリンが得られるはずであると考えられる。緩 衡溶液中のベンザルアニリンの波高は，水素イオン濃度 に関する 1 次反応として減少し, 長時間の後に忤 1 波 は消滅し，第 2 波（ベンザルデヒド）だとなる。これ も，平衡の考壳では説明できない，以上のようなチオ七 ミカルバゾンの場合との相異は, 構造上の相異にるとら くものと思放れる。

その後朝日无上り，最近上原氏と討論した結果，上原氏の考察に異論な く，朝日氐か疑問とされていた点は危惧であった旨の怙たよりを頂いた。 (編者注) (以上)

\title{
銅イオンの還元波におよぼす表面活性剤の影響について
}

\section{The Use of Copper Abnormal Wave and of the Rapidly Dropping Mercury Electrode for the Study of the Maximum Suppressor}

\author{
石 橋 雅 我*, 藤 永太一郎*, 佳 藤 昌 蟗* \\ Masayoshi Ismibashi, Taitiro Fujinaga, Masanori Sato
}

\begin{abstract}
緒
言

最近表面活性剂が電極反応江及ぼす影饗䎲ついて数多 くの興味ある報告 ${ }^{(1)}$ 汸が見られるようになった：著者 らは特に銅の単イオンが多くの表面活性剤の共存侍に， 拡散雪流部分に和いて異常波（極小)(たと充代第 1 図) を生ずることに着目し，種々基整的な検討を行った。 の極小波は一般に表面活性剂污水銀滴䒾面に吸着寸るた め生ずるものと考えられるが，支持壏の陰イオン種，溶 液の $\mathrm{pH}$, 表面活性剤の種類や濃度などによって複椎な 現象を示し，理論的解明を困矆にしている。これらつ研 究結果の詳細䎲ついては，さらに別報する予定であり(8), ここでは要点だけを述べる.
\end{abstract}

\section{実 験 結 果}

極小波現象についての検討結果を概括すれば以下の上 ろである。

1）極小波の生ずる電位：一般極小波現象が最も頙 著に現われるのは電気毛管極大の電位（約 $-0.6 \mathrm{~V} \mathrm{vs.}$ S.C.E.) である.

2）表面活览剤の種類：ゼラチン，ポリアクリルアマ $1 ト ゙(\mathrm{PAA})^{(s)}$, Triton $\mathrm{X}-100$, カンファーなどについ

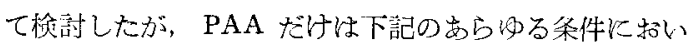
て全然異常現象を示さ仿かった。

3) 酸の種類：過塩素酸：硝酸、硫酸、リン酸などを 用いた結果，それだれの場合，極小波の波形は種々罢

* 京都大学理学部化学教空 (京都吉友京区吉田本町)

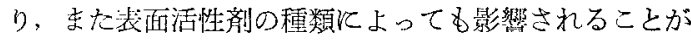
わかった，たと觉ばゼラチンを用いた場合，過㙁素酸溶 液中では銅の罯元波の形が顕著にくずれ緩徐な電流上异 を示寸ようになる、硫酸溶液中では一度拡散電流に達し てから極小波を示し， $-0.6 \mathrm{~V}$ (vs. S.C.E.) 近傍で最小 になる。硝酸溶液中では $-0.7 \mathrm{~V}$ 近傍上り正側で, 単飞 限界留流の值が各電位で同程度に減少するだけで一見し たところ，異常波のようには見られない。

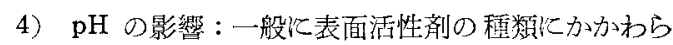
ず,酸性分強くなる程極小現象の現われ方は大きくなる。 たざし例外として，硝酸の場合だけは中性では極小波を 生じないで， $0.1 \mathrm{~N}$ 程度の場合に極小波の起る程度が最 る顕著になり，それより酸性が強くなるに従って徐々に

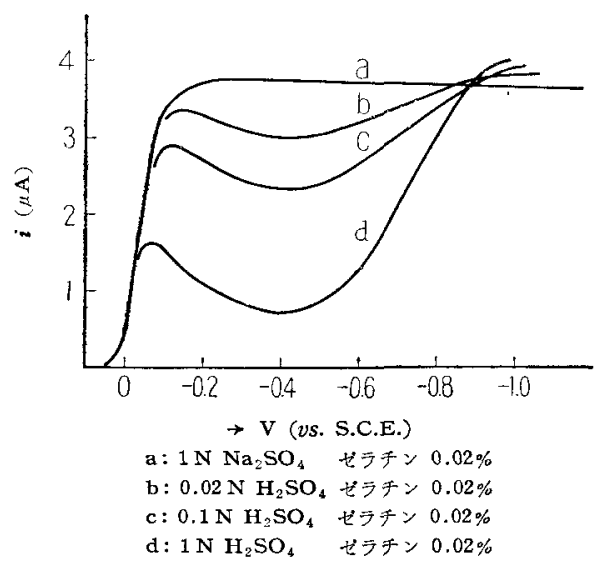

符 1 图 $\mathrm{Cu}^{2+}$ 波に対する $\mathrm{H}^{+}$の影響 


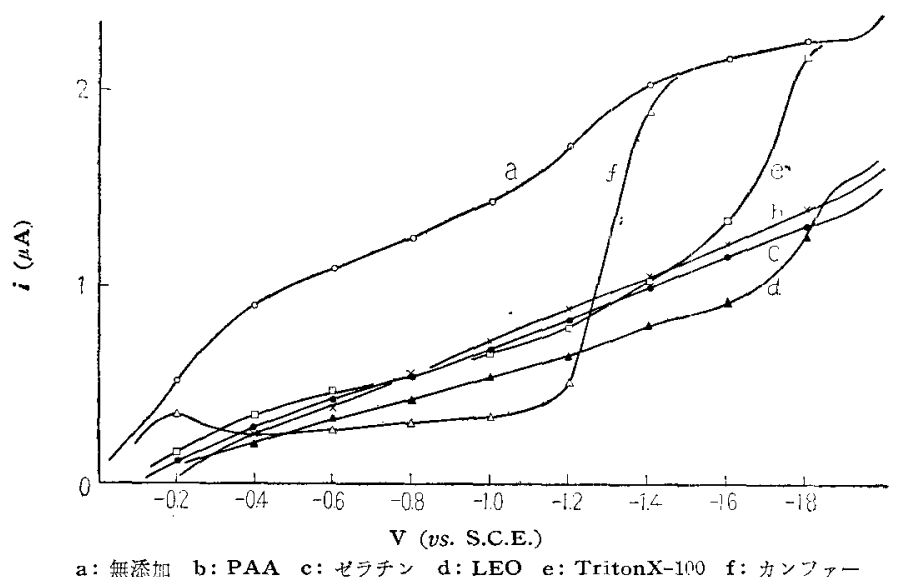

第2図 $1 \mathrm{M}-\mathrm{NaClO}_{4}$ 中に和ける表面活性洞の残余電流 (RADME)

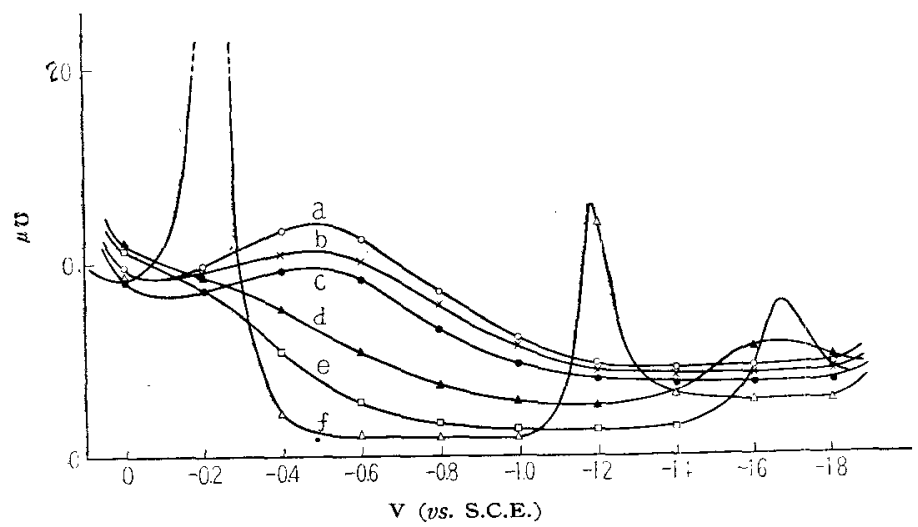

$\mathrm{a}$ ：無添加 b: PAA c: 计ラチン d: LEO e: Triton X-100 f: カンファー

転滴下水銀電極を用いなくても容易に本 方法によって表面活性剤の水銀滴表面へ の脱吸着の電位を明確汇知りうることが わかった.たと充ば 0.01\% カンファー は $-0.3 \sim-1.1 \mathrm{~V}$ (vs. S.C.E.) の範囲 内でだけ吸着し，0.005\% Triton X-100 は - $1.6 \mathrm{~V} て ゙$ 脱着することが明示され る.これ炕対して PAA 扔よびゼラチン は最終電流上昇まで全電位範国にわたっ て吸着していることが明示される。

\section{結論}

これらの結果より，理想的な極大抑制 戍は，その具備すべき条件として次の 2

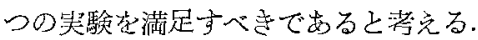

1）迅速滴下水銀電極法（あるいは宁 ンサメトリー，回転滴下水銀雷極法な ぞ）によって全電位笧囲にわたって脱着 が起らない。

2） $1 \mathrm{~N}$-過塩素酸 $1 \mathrm{mM}$-硫酸銅上り なる電解液（ハロゲン・イオンを含季な い）に $0.01 \%$ 以上加党て事極小波を生 じい、すをわち、この実験（1）ょり 全電位領域炕わたって極大を抑制さる一 次吸着首弥形成されるか否か，事た実験 （2）上り拡散層を妨害するような二次 吸着原が栏成されるか否かが判定され る. 結局理想的な極大抑制剤は一次吸着 層は形成するが，水銀滴の生長の間飞は

また，睍犰方が少くなり，1Nでははら゙元の状態に间 復する。

5) 表面活性郕の濃度：一般に呩度の増大とともに極 小現象は大きくなりある程度以上では忹ら゙一定にな

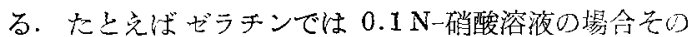
濃度が 0.04，程度委で急速に極小波の程度が大き なるが，それ以上濃度が増加しても，電流值は初めの約 2/5 の大きさで，任一定の值になる。これに效しPAA

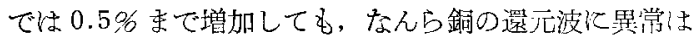
認めら机なかった。

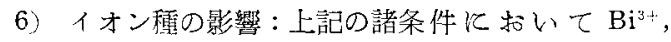
$\mathrm{Fe}^{3+}, \mathrm{Pb}^{2+}, \mathrm{Cd}^{5+}$ などについて検討した結果 $\mathrm{Cd}^{2+}$ に数 似の傾问が名礼るが，他のイオンは極小現象を示さ心 加た.

さらにこの極小波現象の機構を交流ポーラログラフ法 (テンサメトリ一)，迅速滴下水銀電極を用い一㮝討し た. 特に後者を用いれば，水鎾滴表面の流動，荷雷々流 なぞが通常の滴下電極の場会以比して大きいため，残余 電流だけでも寸でに明膫に第 2 程極大波を生ずるので间
二次吸着凅を形成しないということが必要であると考党 られ，たと党ばPAAはこの条件を满足するものである ことが明らがなった。

(明 33-11-14 受理)

\section{文 献}

(1) J.J. Lingane: Ind. Eng. Chem, Anal. Ed., 15, 583 (1943)

(2) J. Heyrovsky: Discuss. Faraday Soc., No.1, 212 (1947)

(3) A.N. Frumkin: Ibid!., No. 1, 224 (1947)

(4) M. Dratovsky et al.: Chem. Listy, 48, 498 (1954)

(5) R.W. Schmidt et al. : J.A.C.S., 80, 2087 (1958)

(6) P. Delahay: Ibid., 80, 2094 (1958)

(7) H.A. Laitinen et al.: Ibia., 80, 2623 (1958)

（8）石橋雅楸，藤永太一郎，佐藤晶憲：日化投稿中

(9) I.M. Kolthoff et al.: Anal. Chim. Acta, 18, 295 (1958)

\section{討論要旨}

玉虫佮太(染北大) テンサメトり一の結果を多る そ, PAA \& LEO や Triton X-100 に比べて容量を低

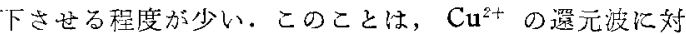
する PAA の影響が LEO や Triton X-100 の影響よ り小さいことと関係があるのでする5か。

藤永太一郎 ごく定性的なこしかい党ないが，少く とも $\mathrm{Cu}^{2+}$ の疅元波の異常現象は，強い吸着(したがっ

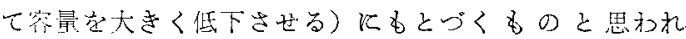


る。PAAもこのようと強い吸着層を形成するか子知れ ないが，少くをも水鋇滴の滴下時間の間には，水䠦滴の 流動を止める程度の弱い吸着しか括こらないるのと思

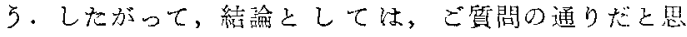
3.

品川㓐明（広大） 1. PAA の棈造飞ついて和同い したい，2． $-\mathrm{CO}-\mathrm{NH}_{2}$ 基があれば両性を示し，乙たが ってゼラチンと同様電気毛管極大のいずれの側でも吸 着可能である.これが,吸着箐囲が大变広いという特徽の 愿因である5。な和，PAA はゼラチンよりもゆるく吸 着しているのではないかと思われるがどうであるうか。

藤永 1．PAA の楧造は次式のょ了にいわれている

$$
\left[\begin{array}{c}
-\mathrm{CH}-\mathrm{CH}_{2}- \\
\mathrm{CONH} \\
\mathrm{CONH}_{2}
\end{array}\right]_{x}(x \text { D值出不明 })
$$

重合度飞よって3種菏販されている (American Cyanamid Co.).いずれるポーラログラフ约机似た性質を

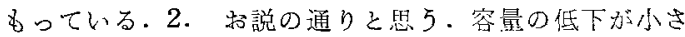
いことからみても吸着層が強固なものではないこが推 察される。

田中信行（東北大） 1. RADMEKより脱吸清の電 位测定する笑験は大变興跨深いもので，RADMEのす ぐれた応用と思5.2. ポーラロダラフ莭論会 (1958, 仙台) 講演要旨集, p. 18 上図については，次の上う火 一一藤永氏の括考光と同じと思われるが-一説明できる
と思う。すなわち，電抜管極大の正の側でTriton X

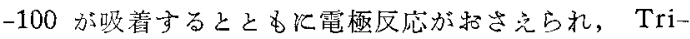
ton X-100 の吸着量唯增加するK従い可逆的邀元の割

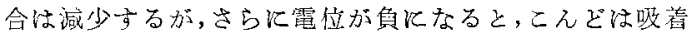
層を通しての韭可逆的還元が特こる。この而者汃組合さ れた結果として，四のような電流一電圧曲線が党られる。 このような考克方は，すでに Dr. Gierst《よって提出 されている [L. Gierst, “Cinétique d’approche et réactions d'électrodes irréversibles", Université Libre de Bruxelles, 1958]. 先に玉虫氏の質問にむった，界面 活性物質の容量に及ぽす影響と，電流一霹正幽線に及に す影響との問題は，このような芳え方をすれば，両考が 必ずし平行的なるのであると考えなくてもよいことに なる、何败なら，吸着すること炕よってか总って電子小 移行を优進するような物質があってもよいのではなか と思われるからである。すっとも，このような物筫が実 際出るかどうか現在のところ不明で㤝るが。

藤永 そのような模型を考克ることには，引れわれと しても替成である.Dr，Reilleyなどの電流一㭙間曲線沉

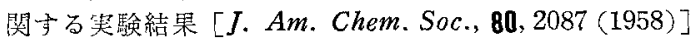

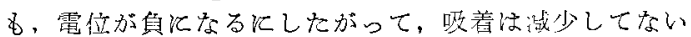

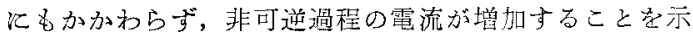
している。このことは，田中氏の述べられた考光方学支 持するbのと思 $ら$.

(以ㄴ)

\section{滴下水銀電極におけるクロノポテンシオメトリー}

\section{Chronopotentiometry at the Dropping Mercury Electrode. Especially the Use of the Slow Dropping Mercury Electrode (SDME)}

不 橋 雅 義*, 藤永太一郎*, 斎藤篤義*, 伊豆洪公估* Masayoshi Ishibashi, Taichiro Fujinaga, Atsuyoshi SAIto, Kosuke IzUTSU

\section{1. 緒言}

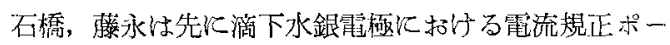
ラログラフィーを創案し，艺の方法と理論とについて報 告したが:(1)-(3), その後千田, 神原, 竹盛 ${ }^{(4)}$, Kolthoff, Okinaka ${ }^{(5)}$ ら本法飞ついて理論的括よび尖験的検討を 行った.

著者らほ今回電流替正ポーシログラフィーに和ける滴

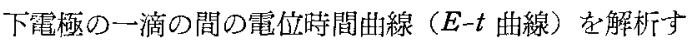
るとともに，クロノポテンシォメトリーの観点から本法 の分析化学への応用の可能性佂つき研究した．その結果 の詳細はさらに别報する予定であり，こへでは要点だけ を述べる。

\section{2. 理論}

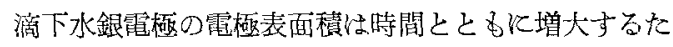
めに, 定霄流で電解を行万場合の乞の $E-t$ 曲線は普通

\footnotetext{
* 京都大学理学部化学教室(京都市方京区吉町本町)
}

の静上雪極の場合と異る多くの特徴圶持っている，電位 は滴が落下しれ瞬間に最名負になり，滴の生長とさもに

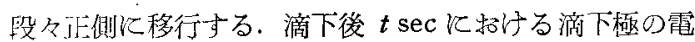
位はポーラログラフ法からつぎのようにして知ることが できる。なわち，各電位に挌けるポーラログラフ的な

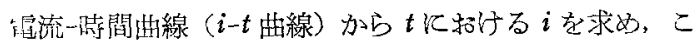
れを界いて瞬間 $t$ K招ける電流電位曲線 $(i-E$ 曲線)

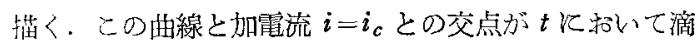
下極加示与電位に相当する。

1. 多量支持電解質溶液中の被還元物筫 $O_{x}$ のポーラ ログラフィ一に括ける $i-t$ 曲線が限界電流域において $i=K C t^{1 / x}$ て表わされると仮定する. $(K$ は定数，CはO の母液溊度， $t$ w滴の落下の瞬間少らの時間. Ilkovič 计が成立する場合には $K=708 n D^{1 / 2} m^{2 / 3}, x=6$ であり

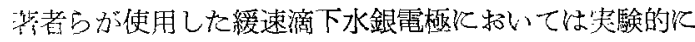

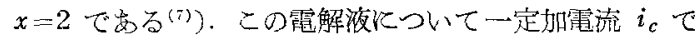

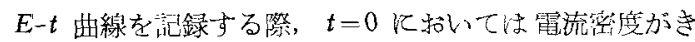

